\title{
Positron Annihilation Spectroscopy of Nanostructural Features in Model Reactor Pressure Vessel Steels
}

S.C. Glade, B.D. Wirth, P. Asoka-Kumar, P.A. Sterne, G.R. Odette

This article was submitted to

$13^{\text {th }}$ International Conference on Positron Annihilation

Kyoto, Japan

September 7-13, 2003

Lawrence

Livermore

National

Laboratory

\section{July 16, 2003}

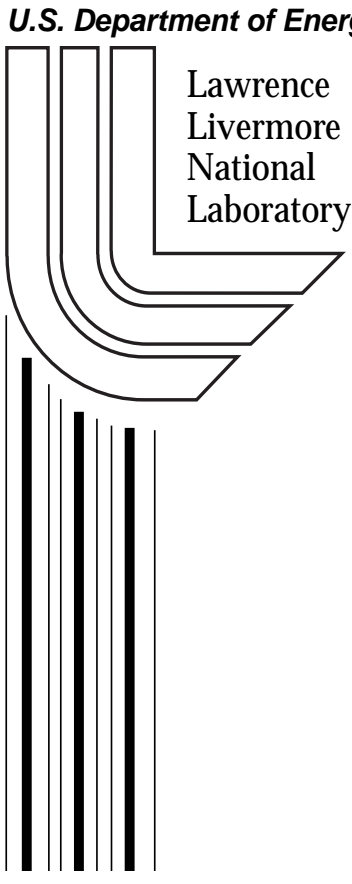




\section{DISCLAIMER}

This document was prepared as an account of work sponsored by an agency of the United States Government. Neither the United States Government nor the University of California nor any of their employees, makes any warranty, express or implied, or assumes any legal liability or responsibility for the accuracy, completeness, or usefulness of any information, apparatus, product, or process disclosed, or represents that its use would not infringe privately owned rights. Reference herein to any specific commercial product, process, or service by trade name, trademark, manufacturer, or otherwise, does not necessarily constitute or imply its endorsement, recommendation, or favoring by the United States Government or the University of California. The views and opinions of authors expressed herein do not necessarily state or reflect those of the United States Government or the University of California, and shall not be used for advertising or product endorsement purposes.

This is a preprint of a paper intended for publication in a journal or proceedings. Since changes may be made before publication, this preprint is made available with the understanding that it will not be cited or reproduced without the permission of the author.

This report has been reproduced directly from the best available copy.

Available electronically at http://www.doc.gov/bridge

Available for a processing fee to U.S. Department of Energy

And its contractors in paper from

U.S. Department of Energy

Office of Scientific and Technical Information

P.O. Box 62

Oak Ridge, TN 37831-0062

Telephone: (865) 576-8401

Facsimile: (865) 576-5728

E-mail: reports@adonis.osti.gov

Available for the sale to the public from

U.S. Department of Commerce

National Technical Information Service

5285 Port Royal Road

Springfield, VA 22161

Telephone: (800) 553-6847

Facsimile: (703) 605-6900

E-mail: orders@ntis.fedworld.gov

Online ordering: http://www.ntis.gov/ordering.htm

OR

Lawrence Livermore National Laboratory

Technical Information Department's Digital Library

http://www.llnl.gov/tid/Library.html 


\title{
Positron Annihilation Spectroscopy of Nanostructural Features in Model Reactor Pressure Vessel Steels
}

\author{
S.C. Glade ${ }^{1 *}$, B.D. Wirth ${ }^{2}$, P. Asoka-Kumar ${ }^{1}$, P.A. Sterne ${ }^{1}$, and G.R. Odette ${ }^{3}$ \\ ${ }^{1}$ Lawrence Livermore National Laboratory, Livermore, CA 94550, USA, *glade1@llnl.gov \\ ${ }^{2}$ University of California Berkeley, Department of Nuclear Engineering, Berkeley, CA 94720, USA \\ ${ }^{3}$ University of California Santa Barbara, Department of Mechanical and Environmental Engineering, \\ Santa Barbara, CA 93106, USA
}

Keywords: positron annihilation spectroscopy, nuclear reactor pressure vessel steels, radiation embrittlement

\begin{abstract}
Irradiation embrittlement in nuclear reactor pressure vessel steels results from the formation of a high number density of nanometer sized copper rich precipitates and sub-nanometer defect-solute clusters. We present positron annihilation spectroscopy (PAS) results to characterize the compositions and magnetic character of these defects in model A533B reactor pressure vessel steels. The results confirm the presence of copper-rich precipitates after irradiation. The measured orbital electron momentum spectra indicate the precipitates are alloyed with $\mathrm{Mn}$ and $\mathrm{Ni}$. The copper precipitates larger than $\mathrm{R} \sim 1.2 \mathrm{~nm}$ (from SANS measurements) are non-magnetic, which limits the possible $\mathrm{Fe}$ content of the precipitates to at most a few \%. Notably, large vacancy clusters observed in neutron irradiated $\mathrm{Fe}-\mathrm{Cu}$ alloys were not observed in the steels after irradiation.
\end{abstract}

\section{Introduction}

The continued operation or lifetime extension of a number of nuclear power plants around the world requires an understanding of the damage imparted to the reactor pressure vessel (RPV) steel by irradiation. Nanometer sized copper-manganese-nickel rich precipitates have been identified as the primary embrittling feature in RPV steels with greater than 0.05 to $0.1 \mathrm{wt} . \% \mathrm{Cu}$ [1]. A secondary embrittling feature has been identified as three-dimensional, sub-nanometer vacancy-solute copper complexes, called stable matrix features $[2,3]$. In this article, we present the results of a positron annihilation spectroscopy (PAS) study on model A533B reactor pressure vessel steels.

\section{Experimental Procedure}

The steels used in this study were the UCSB Laval model split-melt commercial A533B-type Fe$\mathrm{Cu}-\mathrm{Mn}-\mathrm{Ni}-\mathrm{Si}-\mathrm{Mo}-\mathrm{C}$ reactor pressure vessel steels with single variable $\mathrm{Ni}$ variants. The two steels had nominal compositions (in weight percent) of $\mathrm{Fe}-0.41 \% \mathrm{Cu}-0.85 \% \mathrm{Ni}-1.44 \% \mathrm{Mn}$ (LC) and $\mathrm{Fe}-0.38 \% \mathrm{Cu}-1.25 \% \mathrm{Ni}-1.38 \% \mathrm{Mn}(\mathrm{LD})$. The steels were given an austenizing heat treatment at $900{ }^{\circ} \mathrm{C}$ for 1 hour followed by an air cool, followed by a 4 hour temper at $664{ }^{\circ} \mathrm{C}$ and air cool. The alloys were finally given a stress relief heat treatment at $600{ }^{\circ} \mathrm{C}$ for 40 hours, followed by a furnace cool to $300{ }^{\circ} \mathrm{C}$. Specimens in the form of $\sim 1 \mathrm{~cm} \times \sim 1 \mathrm{~cm} \times \sim 2 \mathrm{~mm}$ coupons were irradiated under the conditions listed in Table 1.

Table 1 - Neutron irradiation conditions used in this study. All irradiations were performed at $\mathrm{T}=290^{\circ} \mathrm{C}$.

Positron Annihilation Spectroscopy PAS is a well-established technique for detecting open volume regions of a material (positron annihilation lifetime spectroscopyPALS) [4], as well as the chemical identity of

\begin{tabular}{lll}
\hline $\begin{array}{l}\text { Irradiation } \\
\text { Designation }\end{array}$ & $\begin{array}{l}\text { neutron flux } \\
{\left[\phi\left(\mathbf{n} / \mathbf{m}^{2}-\mathbf{s}\right)\right]}\end{array}$ & $\begin{array}{l}\text { neutron fluence } \\
{\left[\phi \mathbf{t}\left(\mathbf{n} / \mathbf{m}^{2}\right)\right]}\end{array}$ \\
\hline T5 & $8.0 \times 10^{15}$ & $1.4 \times 10^{23}$ \\
T6 & $1.0 \times 10^{16}$ & $3.4 \times 10^{23}$ \\
T11 & $3.0 \times 10^{15}$ & $4.0 \times 10^{21}$ \\
T12 & $3.0 \times 10^{15}$ & $1.0 \times 10^{22}$ \\
T13 & $3.0 \times 10^{15}$ & $2.4 \times 10^{22}$ \\
T14 & $3.0 \times 10^{15}$ & $4.8 \times 10^{22}$ \\
T15 & $3.0 \times 10^{15}$ & $8.5 \times 10^{22}$ \\
T16 & $3.0 \times 10^{15}$ & $1.6 \times 10^{23}$
\end{tabular}


the elements surrounding these open volume regions (orbital electron momentum spectroscopyOEMS) [5]. Thus far, only OEMS has been preformed on these steels, but PALS measurements are currently underway. A new spin-polarized, magnetic positron annihilation technique [6] was also employed, giving a measure of the magnetic character of the region in which the positron annihilated.

\section{Results/Discussion}

OEMS for the LC $(0.85 \% \mathrm{Ni})$ and LD $(1.25 \% \mathrm{Ni})$ steels are presented in Fig. 1 . The spectra, normalized to the unirradiated LC or LD control, for the irradiated alloys clearly indicate copper and nickel, as seen by the peak at $\mathrm{p}_{\mathrm{L}} \sim 3$ atomic units (a.u.). In LC $(0.85 \% \mathrm{Ni})$, the copper/nickel signal increases with increasing fluence from the T11 irradiation to saturation at the T14 irradiation. LD specimens have thus far been measured only in the three high fluence conditions (T5, T6 and T16), and the OEMS are comparable in each irradiation condition. No peak is observed in the low momentum region of the OEMS ( $\mathrm{p}_{\mathrm{L}}<0.75$ a.u.) following irradiation for either steel, indicating that vacancy clusters are not formed in these steels, in contrast to irradiated $\mathrm{Fe}-\mathrm{Cu}$ model alloys in which vacancy clusters are detected $[2,7]$.
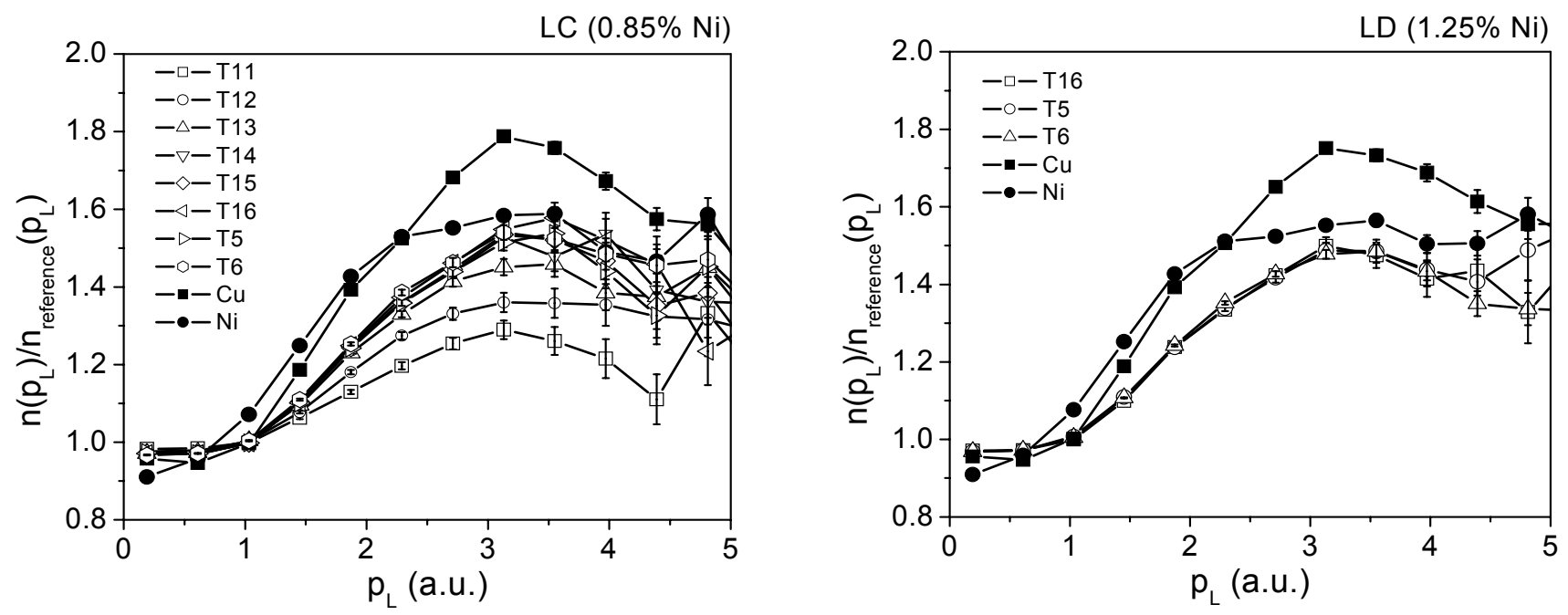

Figure 1 - Orbital electron momentum spectra for the LC $(0.85 \% \mathrm{Ni})$ and the LD $(1.25 \% \mathrm{Ni})$ steels irradiated under different conditions (Table 1). The spectra have been normalized to the corresponding un-irradiated reference specimen. The correspondingly normalized curves of elemental $\mathrm{Cu}$ and $\mathrm{Ni}$ are shown for comparison.

The magnetic character of the precipitates have been determined from spin-polarized, magnetic positron annihilation measurements, as described in more detail in ref. [6]. Fig. 2 presents the results obtained for the irradiated LC $(0.85 \% \mathrm{Ni})$ and LD $(1.25 \% \mathrm{Ni})$ steels. The unirradiated controls of both LC and LD, exhibit a split in the two points with the magnetic field oriented parallel and anti-parallel to the positron spin, similar to the iron sample. With the exception of the relatively low neutron dose T11 and T12 irradiations of LC, the two points nearly super-impose for all irradiated samples, with a significant reduction in the splitting, similar to the copper sample. The small splitting in the T11 and T12 irradiations is possibly due to smaller precipitate sizes in these alloys, as determined from small angle neutron scattering (SANS) measurements, in which the positron is not fully confined (localized); with increasing neutron fluence, the precipitates grow to larger size with complete positron confinement. The lack of splitting between the two points with magnetic field reversal is an indication of non-magnetic behavior at the region of positron 
annihilation, discounting the notion that the precipitates contain significant quantities of $\mathrm{Fe}$ and providing an upper limit of at most a few percent Fe in the precipitates.
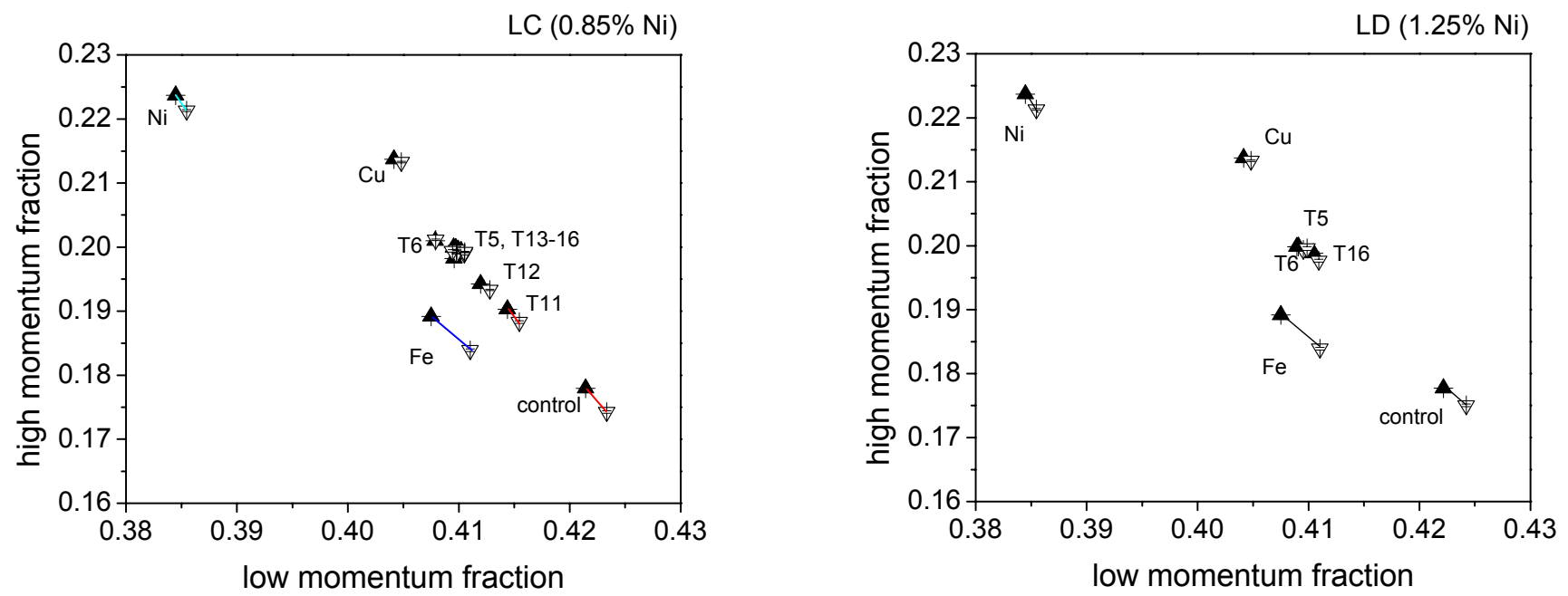

Figure 2 - Results of the spin-polarized, magnetic positron annihilation measurements. Positron annihilation fraction with high momentum (1-4 a.u.) versus low momentum ( $<0.38$ a.u.) electrons, normalized to the total annihilations, for the magnetic field oriented parallel $(\boldsymbol{\Delta})$ and anti-parallel $(\nabla)$ to the positron polarization. Elemental $\mathrm{Fe}, \mathrm{Cu}$, and $\mathrm{Ni}$ are shown as well.

\section{Acknowledgements}

This work was performed under the auspices of the U.S. Department of Energy by the University of California, Lawrence Livermore National Laboratory under Contract No. W-7405-Eng-48 and partially supported by the U.S. Nuclear Regulatory Commission. We acknowledge the contributions of Doug Klingensmith (UCSB).

\section{References}

[1] Odette, G.R., 1983, Scripta Met. 11, 1183.

[2] Wirth, B.D., Asoka-Kumar, P., Howell, R.H., Odette, G.R., and Sterne, P.A., 2001, Mictostructural Processes in Irradiated Materials-2000, Materials Research. Society Symposium Proceedings, Vol 650 (Warrendale, Pennsylvania: Materials Research Society), pp R6.5.1 -R6.5.6.

[3] Wirth, B.D., Asoka-Kumar, P., Howell, R.H., Odette, G.R., and Sterne, P.A, 2003, "Positron Annihilation Spectroscopy and Small Angle Neutron Scattering Characterization of Nanostructural Features in Irradiated Fe-Cu-Mn Alloys," submitted to J. Nucl. Mat.

[4] Hautojärvi, P. (Editor), 1979, Positrons in Solids, (Heildelberg, Topics in Current Physics, Vol. 12)

[5] Asoka-Kumar, P., Alatalo, M., Ghosh, V.J., Kruseman, A.C., Nielsen, B., and Lynn, K.G., 1996, Phys. Rev. Lett. 77, 2097.

[6] Asoka-Kumar, P., Wirth, B.D., Sterne, P.A., and Odette, G.D., 2002, Phil. Mag. Lett. 82, 609.

[7] S.C. Glade, B.D. Wirth, P. Asoka-Kumar, G.R. Odette, P.A. Sterne, and R.H. Howell, 2003, "Positron Annihilation Spectroscopy and Small Angle Neutron Scattering of the effect of MN on the Nanostructural Features formed in Irradiated Fe-Cu-Mn Alloys," submitted to Phil. Mag. 